\title{
PROFIL KEMAMPUAN MAHASISWA CALON GURU BIOLOGI DALAM MENGOMUNIKASIKAN HASIL PRAKTIKUM FISIOLOGI HEWAN
}

\author{
Y. Astuti ${ }^{1}$, R. Suciati ${ }^{2}$ \\ 1,2 Jurusan Pendidikan Biologi \\ Universitas Muhammadiyah Prof. DR. Hamka, Indonesia \\ e-mail: ohm_yunie@yahoo.com ${ }^{1}$
}

\begin{abstract}
Abstrak
Masalah pokok dalam penelitian ini adalah menganalisis profil kemampuan komunikasi mahasiswa calon guru Biologi dalam menyusun laporan praktikum mata kuliah Fisiologi Hewan. Penelitian ini menggunakan metode deskriptif kuantitatif. Skor laporan praktikum direratakan lalu dianalisa secara deskriptif. Hasil yang diperoleh adalah kemampuan calon guru Biologi dalam mengomunikasikan hasil praktikum dikategorikan cukup dan cenderung mengalami peningkatan. Rerata skor laporan praktikum 1, 2, dan 3 , secara berturut-turut sebesar 1,$72 ; 2,03$; dan 2,31. Selain itu, aspek penilaian "terdapat ketepatan sistematika penulisan laporan praktikum" mengalami peningkatan. Penyusunan laporan praktikum sudah sesuai dengan sistematika penulisan yang baik. Aspek penilaian "kemampuan mengolah data temuan secara tepat" dan "relevansi penggunaan teori dalam menganalisis data temuan" juga mengalami peningkatan, dengan rerata skor masing-masing adalah 1,10 menjadi 2,27 dan 1,27 menjadi 2,17. Jadi, dapat disimpulkan bahwa kemampuan komunikasi calon guru Biologi dalam penyusunan laporan praktikum mata kuliah Fisiologi Hewan dikategorikan cukup. Pemberian feedback dinilai efektif dalam peningkatan kemampuan tersebut.
\end{abstract}

Kata Kunci: Kemampuan Komunikasi, Mahasiswa, Biologi

\section{Abstract}

The main problem in this research is to analyze the profile communications skill of Biology's student teachers in preparing the report practicum course on Animal Physiology. The research method used is descriptive quantitative method. Data (score of practical reports) is averaged then analyzed descriptively. The results are the ability of prospective biology teacher in communicating the practical results fall into the category enough and tends to increase. Mean score of practical report 1,2 , and 3 respectively $1.72 ; 2.03 ; 2.31$. In addition, aspects of assessment "are precision systematic writing lab report" increased. Preparation of practical reports are in accordance with the systematics of good writing. Aspects of assessment "ability to process data accurately findings" and "relevance of theories in analyzing the data findings" also increased, with the average score of each is 1.10 to 2.27 and 1.27 to 2.17. So it can be concluded that a prospective biology teacher communication skills in the preparation of practical reports on subjects Physiology categorized enough. Giving feedback is considered effective in improving the ability of it.

Keywords: Communicate skill, College Students, Biology

\section{PENDAHULUAN}

Perkembangan kemajuan ilmu pengetahuan dan teknologi suatu bangsa tidak terlepas dari peranan penelitian dan pendidikan. Beberapa penelitian di berbagai aspek kehidupan banyak dilakukan, baik di negara maju maupun berkembang. Hasil penelitian yang telah dicapai oleh para peneliti harus disampaikan kepada masyarakat secara komunikatif. Hal tersebut dilakukan agar masyarakat dapat menerima informasi hasil penelitian dengan benar. Untuk itu, para peneliti 
hendaknya memiliki kemampuan untuk mengomunikasikan hasil penelitiannya secara jelas dan menarik.

Tak jauh berbeda dengan peneliti, mahasiswa pendidikan Biologi juga hendaknya memiliki kemampuan untuk mengomunikasikan hasil praktikum dalam bidang Biologi. Kemampuan komunikasi merupakan salah satu Keterampilan Proses Sains (KPS) yang harus dimiliki dan dilatihkan kepada mahasiswa Pendidikan Biologi sebagai suatu upaya pengembangan potensi mahasiswa. Hal tersebut tercantum dalam Undang-Undang Sistem Pendidikan Nasional (UUSPN) No. 20 Tahun 2003 yaitu pendidikan adalah usaha sadar dan terencana untuk mewujudkan suasana belajar dan proses pembelajaran agar peserta didik secara aktif mengembangkan potensi dirinya untuk memiliki kekuatan spiritual keagamaan, pengendalian diri, kepribadian, kecerdasan, akhlak mulia, serta keterampilan yang diperlukan dirinya, masyarakat, bangsa, dan negara (Depdiknas, 2003).

Biologi merupakan cabang ilmu yang memiliki peranan yang sangat besar bagi kehidupan, karena mempelajari segala sesuatu mengenai makhluk hidup. Salah satu cabang ilmu Biologi yang dipelajari oleh mahasiswa calon guru Biologi adalah Fisiologi. Rumanta (2007) menjelaskan bahwa fisiologi adalah suatu bidang ilmu yang secara khusus mempelajari aktivitasaktivitas fungsional yang terjadi di dalam tubuh makhluk hidup dalam rangka mempertahankan kelangsungan hidupnya. Di perguruan tinggi, bidang keilmuan ini tertuang dalam mata kuliah Fisiologi Hewan. Menurut silabus yang ada di salah satu perguruan tinggi swasta di Jakarta, mata kuliah Fisiologi Hewan membahas tentang prosesproses hidup dan aktivitas yang terjadi dalam tubuh hewan, meliputi cairan tubuh dan gerakan substansi melintasi membran, darah dan peredaran darah, nutrisi dan pencernaan makanan, pertukaran gas, osmoregulasi dan ekskresi, termoregulasi, otot, saraf, hormon, dan reproduksi. Sebagai salah satu bidang ilmu Biologi, Fisiologi
Hewan memiliki tujuan yaitu memahami konsep-konsep keterkaitan fungsi organ-organ yang menunjang metabolisme tubuh hewan. Sehingga menurut Rustaman, Soendjojo, Suroso, Yusnani, Ruchji, Diana, dan Mimin (2003), pembelajaran tersebut perlu mengembangkan daya penalaran untuk memecahkan masalah yang dihadapi dalam kehidupan sehari-hari. Pengembangan pembelajaran pada mata kuliah Fisiologi Hewan lebih menekan pada pemberian pengalaman langsung, agar mahasiswa dapat menemukan dan memecahkan masalah yang terkait dengan keterkaitan fungsi organ-organ tubuh hewan sesuai dengan prosedur ilmiah berdasarkan penalaran-penalaran kritis-logis yang menghasilkan fakta-fakta ilmiah.

Kegiatan yang melibatkan prosedur ilmiah didalamnya dapat dilakukan melalui metode praktikum. Praktikum merupakan suatu kegiatan untuk menambah pengertian tentang sikap atau cara kerja sistem tubuh melalui pengamatan secara langsung. Menurut Zaenudin (dalam Rustaman, 2002) secara rinci praktikum dapat dimanfaatkan untuk 1) melatih keterampilan-keterampilan yang dibutuhkan mahasiswa; 2) memberi kesempatan pada mahasiswa untuk menerapkan dan mengintegrasikan pengetahuan dan keterampilan yang dimilikinya secara nyata dalam praktik; 3) membuktikan sesuatu secara ilmiah atau melakukan scientific inquiry; dan 4) menghargai ilmu dan keterampilan yang dimiliki. Praktikum yang dilakukan berdasarkan metode ilmiah dapat membangun kemampuan atau keterampilan dasar bekerja ilmiah. Keterampilan tersebut dikenal dengan Keterampilan Proses Sains (KPS).

Bundu (2006) menjelaskan definisi KPS sebagai wawasan atau anutan pengembangan keterampilanketerampilan intelektual, sosial dan fisik yang bersumber dari kemampuankemampuan mendasar yang prinsipnya telah ada dalam diri mahasiswa. Semiawan, Tangyong, Belen, Yulaelawati, dan Wahjudi (1988) mencantumkan 13 keterampilan proses 
sains, yaitu mengobservasi, menghitung, mengukur, mengklasifikasi, mencari hubungan ruang atau waktu, membuat hipotesis, merencanakan penelitiaan, mengendalikan variabel, menginterpretasikan atau menafsirkan data, menyusun hipotesis, memprediksi, mengaplikasi, dan mengomunikasikan. Salah satu indikator KPS yang dibutuhkan mahasiswa adalah kemampuan mengomunikasikan hasil praktikum Fisiologi Hewan yaitu dalam bentuk laporan praktikum.

Kemampuan melakukan

komunikasi tersebut dapat diidentifikasi berdasarkan hal berikut: 1) memberikan atau mendeskripsikan atau menggambarkan data empiris hasil percobaan atau pengamatan dengan grafik, tabel, diagram, atau mengubahnya dalam bentuk salah satunya; 2) menyusun dan menyampaikan laporan secara sistematis dan jelas; 3) menjelaskan hasil percobaan atau penelitian; 4) membaca grafik, tabel atau diagram; dan 5) mendiskusikan hasil kegiatan suatu masalah atau peristiwa. Tidak jauh berbeda dengan penjelasan Semiawan, Tangyong, Belen, Yulaelawati, dan Wahjudi (1988) bahwa tindakan mengomunikasikan hasil penemuan dapat dilakukan dengan 1) membuat gambar, model, tabel, diagram, grafik, atau histogram; 2) membuat karangan; 3) menceritakan pengalamannya dalam kegiatan observasi; 4) menyajikan laporan hasil diskusi kelompok; dan 5) membuat berbagai pajangan yang dipamerkan di dalam ruang kelas.

Kemampuan mengomunikasikan hasil praktikum sangat dibutuhkan oleh mahasiswa agar hasil yang telah diperoleh dapat tersampaikan dan diterima oleh orang lain secara jelas. Menurut tim dosen Botani Phanerogamae (2002) bahwa terdapat beberapa hal yang harus diperhatikan dalam penyusunan laporan praktikum di antaranya: 1) sistematika laporan harus memenuhi syarat sebagai tulisan ilmiah; 2) kelengkapan dan keakuratan data hasil pengamatan; 3) kemampuan mengolah dan menganalisis data secara kritis dalam diskusi atau pembahasan hasil pengamatan; serta 4) ketepatan penyerahan laporan.

Semiawan, Tangyong, Belen, Yulaelawati, dan Wahjudi (1988) menjelaskan bahwa pendidik perlu melatih mahasiswa tentang kemampuan mengomunikasikan hasil praktikum, misalnya dengan membuat gambar, model, tabel, diagram, grafik, atau histogram. Ketepatan dan kejelasan gambar, model, tabel, diagram, grafik, atau histogram yang disusun oleh mahasiswa dapat menggambarkan ketercapaian tujuan praktikum dan tingkat penguasaan konsep mahasiswa. Sembilan puluh persen mahasiswa yang mengontrak mata kuliah Struktur Hewan belum mampu membuat tabel hasil praktikum secara jelas dan tepat. Isi tabel tidak sesuai dengan tujuan praktikum. Pernyataan tersebut didasari pada temuan di lapangan yang terungkap dalam hasil studi pendahuluan. Studi pendahuluan melibatkan mahasiswa yang mengontrak mata kuliah Struktur Hewan di salah satu LPTK di Jakarta pada tahun akademik 2015-2016. Hasil studi mengungkapkan bahwa kemampuan mahasiswa dalam mengomunikasikan hasil praktikum masih rendah. Temuan lain diungkapkan dalam penelitian yang dilakukan oleh Anugrah (2011), bahwa kemampuan KPS mahasiswa dalam hal klasifikasi, membuat kesimpulan, mengajukan pertanyaan, dan komunikasi masih tergolong dalam kategori sangat kurang dengan nilai rata-rata secara berturut-turut 32,42 ; 12,04; 24,07; dan 25,93. Latar belakang di atas menjadi alasan bagi perlunya diadakan penelitian tentang profil kemampuan mahasiswa calon guru Biologi dalam mengomunikasikan hasil praktikum Fisiologi Hewan.

Penelitian ini bertujuan untuk mendeskipsikan kemampuan komunikasi calon guru Biologi dalam penyusunan laporan praktikum pada mata kuliah Fisiologi Hewan. Selain itu, tujuan penelitian ini adalah untuk mengidentifikasi efektivitas pemberian feedback dalam peningkatan 
kemampuan komunikasi calon guru Biologi dalam menyusun laporan praktikum pada mata kuliah Fisiologi Hewan.

\section{METODE}

Metode yang digunakan pada penelitian ini adalah metode deskriptif kuantitatif. Sukmadinata (2011) menjelaskan bahwa penelitian deskriptif kuantitatif menggambarkan fenomena menggunakan ukuran, jumlah atau frekuensi. Dalam penelitian ini diungkapkan kemampuan komunikasi mahasiswa dalam menyusun laporan praktikum menggunakan skor hasil penilaian terhadap laporan praktikum yang merupakan hasil kinerja mahasiswa. Laporan praktikum yang disusun mencakup tiga materi yaitu praktikum waktu koagulasi darah, frekuensi paru-paru, dan osmoregulasi pada ikan mas. Dosen dan tim penilai memberikan skor dan umpan balik (feedback) terhadap kualitas setiap laporan praktikum hasil kinerja mahasiswa menggunakan rubrik penilaian.

Populasi dalam penelitian ini adalah seluruh mahasiswa program studi Pendidikan Biologi semester VI, yang mengontrak mata kuliah Fisiologi Hewan pada tahun akademik 20152016. Populasi berjumlah 111 mahasiswa. Populasi terdiri dari tiga kelas yaitu kelas A, B, dan C. Sampel yang digunakan dalam penelitian ini adalah kelas C sebanyak 30 mahasiswa. Pemilihan sampel dilakukan dengan cara purposive sampling karena didasarkan atas kriteria diantaranya kelas tersebut bersifat heterogen dan telah memiliki pengalaman dalam menyusun laporan praktikum pada mata kuliah lain.

Teknik pengumpulan data yang dilakukan pada penelitian ini menggunakan studi dokumentasi. Jenis instrumen yang digunakan berupa rubrik dengan metode skala penilaian (rating scale). Rentang skala penilaian yang digunakan dari 1 hingga 3 . Studi dokumentasi dilakukan untuk memperoleh informasi yang bersifat umum tentang format laporan praktikum yang disusun oleh mahasiswa pada beberapa kegiatan praktikum Fisiologi Hewan. Rubrik penilaian memuat beberapa kriteria laporan praktikum ideal sehingga dapat menggambarkan kemampuan mahasiswa dalam mengomunikasikan hasil praktikum.

Mahasiswa menyusun beberapa laporan praktikum pada mata kuliah Fisiologi Hewan. Laporan praktikum yang disusun mencakup tiga materi yaitu praktikum waktu koagulasi darah, frekuensi paru-paru, dan osmoregulasi pada ikan mas. Kriteria penilaian digunakan untuk menghindari subjektifitas dalam penganalisaan data. Kriteria penilaian laporan praktikum meliputi: 1) kejelasan prosedur kerja praktikum; 2) kemampuan mengolah data temuan secara tepat; 3) ketepatan menganalisis data temuan; 4) kesesuaian rumusan simpulan dengan tujuan dan hasil; 5) relevansi penggunaan teori dalam menganalisis data temuan; 6) terdapat ketepatan sistematika penulisan laporan praktikum; dan 7) ketepatan waktu pengumpulan laporan praktikum.

Teknik untuk menghitung skor laporan praktikum dilakukan menurut rumus yang digunakan oleh Wolf and Stevens (2007) dalam penelitiannya sebagai berikut:

Nilai $=\frac{\text { perolehan skor mahasiswa }}{\text { jumlah kriteria penilaian }}$

Data yang terkumpul berupa skor laporan praktikum dianalisa secara deskriptif, yaitu mendeskripsikan atau menggambarkan skor berdasarkan rentang skala 1-3 untuk menggambarkan kemampuan mahasiswa apa adanya. Selanjutnya data diolah sehingga diperoleh penyajian data berupa tabel dan grafik.

\section{HASIL DAN PEMBAHASAN}

Hasil yang diperoleh dalam penelitian ini dikelompokkan menjadi beberapa data berikut: 1) kinerja calon guru Biologi tentang kemampuan mengomunikasikan hasil praktikum dan 2) kemampuan calon guru Biologi pada setiap aspek penilaian dalam 
mengomunikasikan hasil praktikum. Data tersebut akan dijabarkan lebih jelas sebagai berikut.

Kemampuan komunikasi calon guru Biologi dalam penyusunan laporan praktikum meliputi rerata skor tugas kinerja ke-1, kinerja ke-2, dan kinerja ke-
3. Kinerja ke-1 adalah laporan praktikum "Koagulasi Darah", kinerja ke-2 adalan laporan praktikum "Frekuensi ParuParu", dan kinerja ke-3 adalah laporan praktikum "Osmoregulasi pada Ikan Mas". Perolehan rerata skor laporan praktikum tertera dalam Gambar 1.

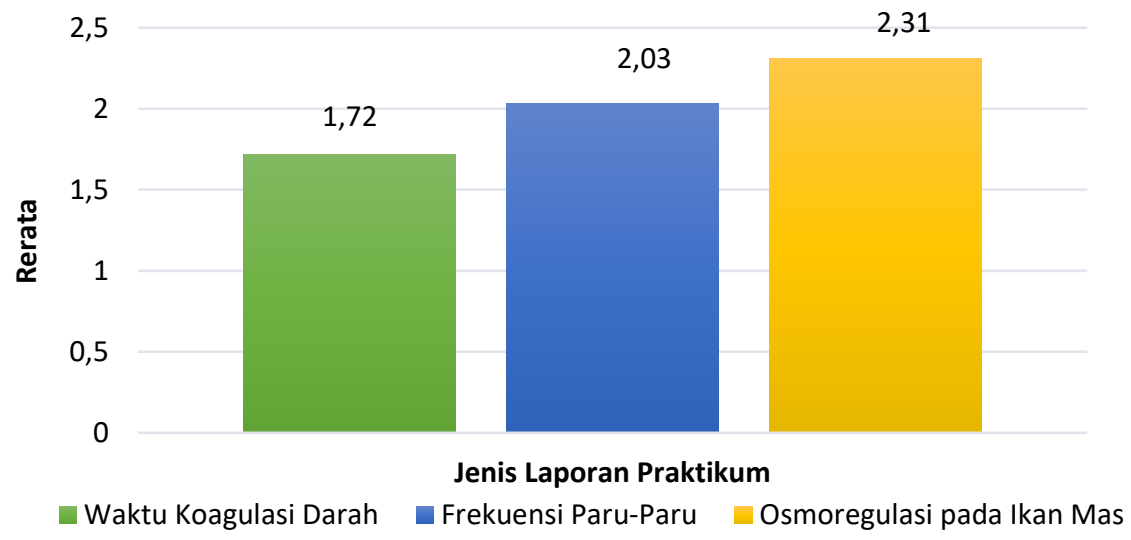

Gambar 1. Rerata Skor Kemampuan Komunikasi Calon Guru Biologi dalam Penyusunan Laporan Praktikum pada Mata Kuliah Fisiologi Hewan

Data dalam Gambar 1. menunjukkan bahwa rerata skor yang diperoleh pada laporan praktikum 1 sebesar 1,72; perolehan rerata skor pada laporan praktikum 2 sebesar 2,03; dan pada laporan 3 adalah 2,31. Kemampuan calon guru Biologi dalam mengomunikasikan hasil praktikum termasuk ke dalam kategori cukup. Hal tersebut disebabkan mahasiswa calon guru Biologi memahami pentingnya laporan praktikum untuk menyampaikan hasil praktikum. Namun, mahasiswa cenderung mengabaikan pengolahan data temuan. Berdasarkan hasil wawancara dengan beberapa mahasiswa, beberapa laporan praktikum yang telah dinilai oleh dosen mata kuliah sebelumnya tidak pernah dikembalikan sehingga mahasiswa tidak mengetahui kelemahan dan kelebihan sebagai umpan balik (feedback) dari laporannya. Dengan demikian, mahasiswa beranggapan bahwa isi laporan praktikum yang disusun selama ini memiliki kualitas yang baik. Mahasiswa yang tidak memperoleh feedback terhadap konsep yang telah diterima sebelumnya tidak akan mengetahui kebenaran konsep yang tertanam dalam dirinya. Hal tersebut sesuai dengan pendapat Gagne yang dikutip oleh Dahar (1996), mengungkapkan bahwa mahasiswa harus memperoleh feedback yang bermakna tentang penampilan mereka, yang menunjukkan apakah mahasiswa telah atau belum mengerti tentang apa yang diajarkan.

Perolehan skor pada setiap laporan praktikum cenderung mengalami peningkatan seperti tertera pada Gambar 1. Peningkatan tersebut dikarenakan pada awalnya mahasiswa belum mempunyai pengalaman tentang teknik penulisaan laporan praktikum yang sesuai dengan standar. Isi dari laporan masih berupa data mentah yang tidak dihubungkan dengan teori. Pada laporan praktikum 3, mahasiswa sudah mengetahui kelemahan yang ada didalamnya melalui feedback yang dituliskan oleh dosen dan tim penilai. Mahasiswa menggunakan feedback 
tersebut sebagai bahan pertimbangan dan pengalaman untuk mengomunikasikan hasil temuan dalam bentuk laporan praktikum. Fakta di atas menunjukkan bahwa pemberian feedback dalam laporan praktikum dapat memberikan penguatan dan lebih berdampak terhadap peningkatan kemampuan mahasiswa. Hal tersebut sesuai dengan pendapat Dahar (1996), feedback dapat memberikan penguatan (reinforcement).

Mahasiswa telah mendapatkan feedback dari tim penilai yang mempunyai pengalaman dalam penyusunan laporan praktikum sehingga dapat membantu mahasiswa melewati Zone of Proximal Development (ZPD) guna mencapai tingkat perkembangan intelektualnya. Mahasiswa dapat mengembangkan kemampuannya dalam mengomunikasikan hasil temuan melalui penyusunan laporan praktikum, ketika mendapatkan bimbingan dari dosen sehingga akan memperkuat hubungan antar konsep yang telah diperolehnya. Pernyataan ini didukung oleh hasil penelitian Jalmo (2010) menyebutkan bahwa program pelatihan peningkatan kompetensi diri menggunakan strategi scaffolding merupakan program yang cukup efektif meningkatkan kompetensi guru IPA SMP melalui tugas-tugas yang menantang dan pembimbingan (scaffolding) berjenjang sesuai dengan kebutuhan peserta.

Laporan praktikum digunakan sebagai media untuk mengetahui kemampuan mahasiswa calon guru Biologi dalam mengomunikasikan hasil temuan. Laporan praktikum yang disusun oleh mahasiswa calon guru Biologi dinilai berdasarkan beberapa aspek penilaian yaitu: 1) kejelasan prosedur kerja praktikum; 2) kemampuan mengolah data temuan secara tepat; 3) ketepatan menganalisis data temuan; 4) kesesuaian rumusan simpulan dengan tujuan dan hasil; 5) relevansi penggunaan teori dalam menganalisis data temuan; 6) terdapat ketepatan sistematika penulisan laporan praktikum; dan 7) ketepatan waktu pengumpulan laporan praktikum. Deskripsi perolehan rerata skor kinerja calon guru Biologi dalam mengomunikasikan hasil praktikum dapat dilihat pada Tabel 1.

Tabel 1. Rerata Skor Kemampuan Calon Guru Biologi dalam Mengomunikasikan Hasil Temuan melalui Laporan Praktikum

\begin{tabular}{|c|c|c|c|c|}
\hline \multirow{2}{*}{ No } & \multirow{2}{*}{ Kriteria } & \multicolumn{3}{|c|}{ Rerata Skor Kinerja ke- } \\
\hline & & 1 & 2 & 3 \\
\hline 1. & Kejelasan prosedur kerja praktikum & 2,17 & 2,60 & 2,87 \\
\hline 2. & Kemampuan mengolah data temuan secara tepat & 1,10 & 1,03 & 2,27 \\
\hline 3. & Ketepatan menganalisis data temuan & 1,27 & 1,33 & 1,87 \\
\hline 4. & $\begin{array}{l}\text { Kesesuaian rumusan simpulan dengan tujuan dan } \\
\text { hasil }\end{array}$ & 1,13 & 1,80 & 1,17 \\
\hline 5. & $\begin{array}{l}\text { Relevansi penggunaan teori dalam menganalisis } \\
\text { data temuan }\end{array}$ & 1,27 & 1,63 & 2,17 \\
\hline 6. & $\begin{array}{l}\text { Terdapat ketepatan sistematika penulisan laporan } \\
\text { praktikum }\end{array}$ & 2,27 & 2,87 & 2,90 \\
\hline 7. & Ketepatan waktu pengumpulan laporan praktikum & 2,87 & 2,93 & 2,93 \\
\hline
\end{tabular}

Keterangan:

Kinerja 1 : Laporan Praktikum "Waktu Koagulasi Darah"

Kinerja 2 : Laporan Praktikum "Frekuensi Paru-Paru"

Kinerja 3 : Laporan Praktikum "Osmoregulasi pada Ikan Mas" 
Perolehan rerata skor kemampuan mahasiswa dalam mengomunikasikan hasil temuan melalui laporan praktikum dapat dilihat lebih jelas pada Gambar 2.

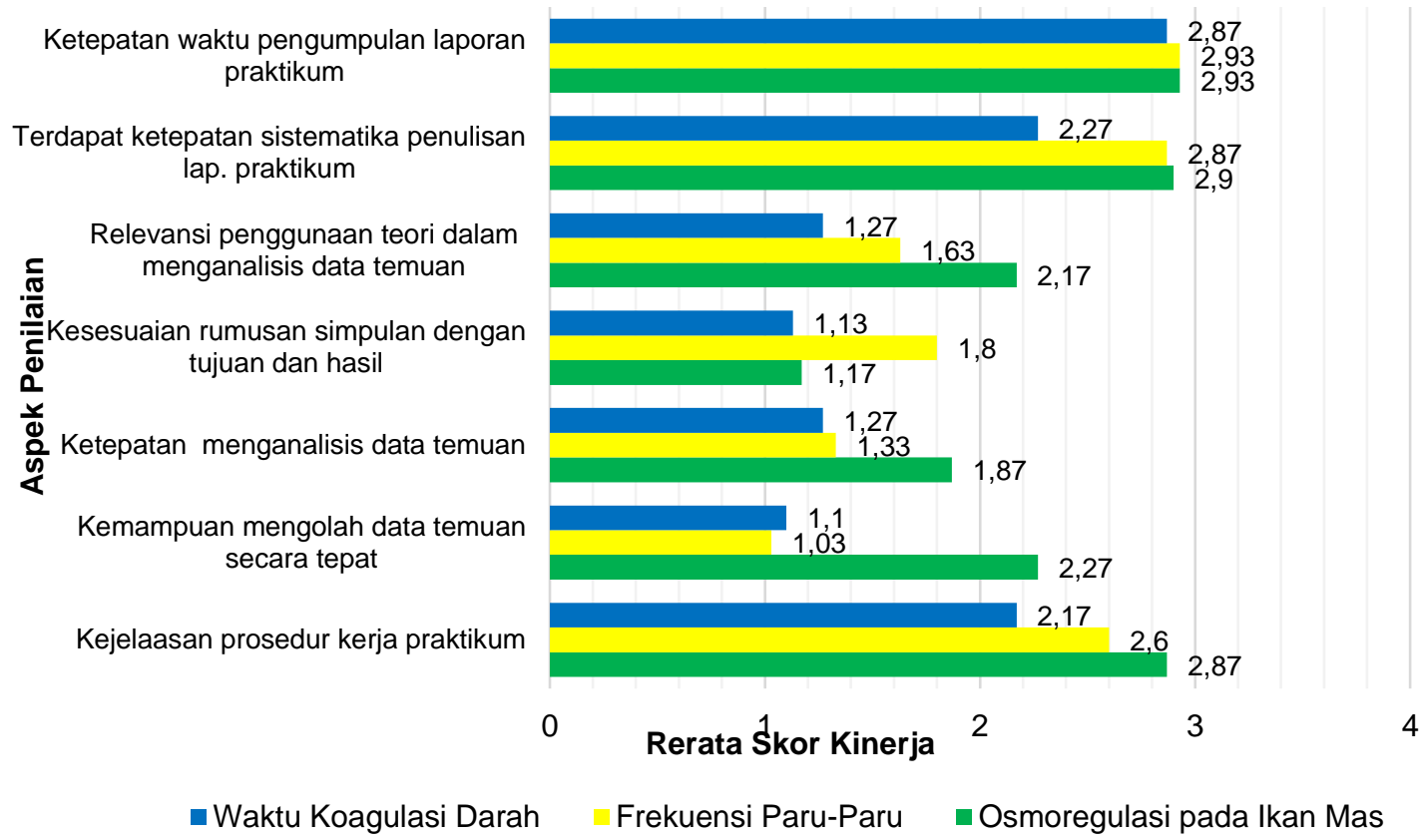

Gambar 2. Rerata Skor Kemampuan Calon Guru Biologi dalam Mengomunikasikan Hasil Temuan melalui Laporan Praktikum

Data dalam Tabel 1 dan Gambar 2. menunjukkan bahwa aspek penilaian "terdapat ketepatan sistematika penulisan laporan praktikum" mengalami peningkatan. Penyusunan laporan praktikum sudah sesuai dengan sitematika penulisan yang baik. Hal tersebut dikarenakan mahasiswa memperhatikan sistematika penulisan yang telah dipaparkan di dalam panduan praktikum. kejelasan petunjuk pada panduan praktikum akan memudahkan mahasiswa dalam mengomunikasikan hasil temuan dalam bentuk laporan praktikum. Tapi mahasiswa kurang memahami tata cara penulisan daftar pustaka terutama yang bersumber dari internet. Mahasiswa belum terlatih untuk menuliskan daftar pustaka sehingga perlu dilatihkan terlebih dulu dan bila perlu diberi contoh penulisan daftar pustaka yang sesuai standar di dalam panduan praktikum. Dalam hal ini, panduan praktikum yang ada mempunyai kekurangan yaitu tidak adanya contoh penulisan daftar pustaka.
Aspek penilaian "kemampuan mengolah data temuan secara tepat" dan "relevansi penggunaan teori dalam menganalisis data temuan" juga mengalami peningkatan, dengan rerata skor masing-masing adalah 1,10 menjadi 2,27 dan 1,27 menjadi 2,17.

Kemampuan mahasiswa calon guru Biologi pada aspek penilaian "kemampuan mengolah data temuan secara tepat", dengan rerata skor masing-masing adalah 1,10 menjadi 2,27 . Aspek "kemampuan mengolah data temuan secara tepat" merupakan kemampuan yang penting dalam mengomunikasikan hasil temuan. Pada kinerja ke-1, mahasiswa hanya menghitung waktu kuagulasi darah setiap 30 detik, sesuai dengan tabel yang terdapat pada panduan praktikum. Mahasiswa tidak menghitung rerata waktu kogulasi darah pada ketiga praktikan sebagai bentuk pengolahan data tersebut. Hal ini disebabkan mahasiswa kurang memperhatikan tujuan praktikum sehingga kurang memahami cara mengolah data. Mahasiswa juga tidak lengkap dalam 
mengisi data waktu koagulasi darah pada tabel. fakta ini menunjukkan bahwa mahasiswa kurang teliti dalam melakukan observasi. Tim dosen Phanerogamae (2002) menjelaskan bahwa data yang disajikan dalam laporan praktikum harus lengkap dan akurat sehingga akan mencerminkan kemampuan praktikan dalam melakukan observasi dengan benar.

Pada kinerja ke-3 yaitu tentang "Osmoregulasi pada Ikan Mas", kemampuan mahasiswa pada aspek "kemampuan mengolah data temuan secara tepat" mulai meningkat. Hal tersebut ditunjukkan dengan adanya grafik hubungan waktu hidup hewan dengan konsentrasi $\mathrm{NaCl}$ yang digambar oleh sebagian besar mahasiswa. Grafik tersebut digambarkan dengan tepat. Berarti kemampuan mahasiswa dalam mengomunikasikan hasil temuan sudah baik jika dilihat dari aspek kemampuan mengolah data temuan secara tepatdi. $\mathrm{Hal}$ tersebut sesuai dengan penjelasan Semiawan (1988) bahwa salah satu indikator komunikasi KPS adalah menggambarkan data dengan grafik, tabel/diagram.

Kemampuan mahasiswa calon guru Biologi pada aspek penilaian "relevansi penggunaan teori dalam menganalisis data temuan" juga mengalami peningkatan, dengan rerata skor masing-masing adalah 1,27 menjadi 2,17. Pada kinerja ke-1, mahasiswa tidak mencantumkan teori secara eksplisit dalam membahas hasil temuan. Teori yang digunakan secara implisit tidak berhubungan langsung dengan data temuan dan cenderung berdiri sendiri atau tidak menjelaskan data temuan yaitu tentang waktu koagulasi darah dan faktor yang mempengaruhinya. Hal tersebut menunjukkan kelemahan mahasiswa dalam mencantumkan kutipan. Berdasarkan catatan lapangan, mahasiswa yang belum terbiasa dalam mencantumkan kutipan untuk mendukung hasil temuan. Pada kinerja ke-3, kemampuan ini sudah mulai meningkat karena mahasiswa sudah mulai memperhatikan feedback yang diberikan oleh tim penilai. Dengan demikian, mahasiswa mengetahui kesalahan yang dilakukan pada laporan sebelumnya dan sudah dapat memperbaikinya. Hal ini sesuai didukung oleh pendapat Gagne yang dikutip oleh Dahar (1996), mengungkapkan bahwa mahasiswa harus memperoleh feedback yang bermakna tentang penampilan mereka, yang menunjukkan apakah mahasiswa telah atau belum mengerti tentang apa yang diajarkan.

Data dalam Gambar 2. menunjukkan kemampuan mahasiswa calon guru Biologi yang masih lemah adalah pada aspek penilaian "ketepatan menganalisis data temuan". Dari kinerja ke-1 hingga ke-3, tampak rerata skor yang diperoleh mahasiswa secara berturut-turut adalah 1,27; 1,63; dan 2,17, berarti kemampuan mahasiswa pada aspek ini belum bagus. Hal tersebut disebabkan mahasiswa belum memahami konten yang terkait dengan praktikum "Waktu Koagulasi Darah", "Frekuensi Paru-Paru", dan "Osmoregulasi pada Ikan Mas" sehingga kesulitan dalam menganalisis hasil temuan.

Mahasiswa kurang bisa menghubungkan antarkonsep yang dapat dijadikan bahan untuk mencari penyebab dari temuan tersebut. Contohnya pada praktikum "Osmoregulasi pada Ikan Mas", mahasiswa sudah tepat dalam menggambar grafik hubungan antara waktu hidup ikan dengan konsentrasi $\mathrm{NaCl}$, yang menunjukkan bahwa pada konsentasi $\mathrm{NaCl}$ yang tinggi waktu hidup ikan tidak lama. Penyebab yang diutarakan oleh mahasiswa terkait dengan temuan tersebut kurang tepat karena mahasiswa tidak menjelaskan proses osmosis berdasarkan perbedaan tekanan osmosisnya. Sembilan puluh lima persen mahasiswa tidak mencantumkan alasan atau penyebab dari data temuan. Kemampuan ini sangat terkait dengan kemampuan berpikir kritis. Faka tersebut sesuai dengan pendapat Tim Dosen Botani Phanerogamae (2002) yang menjelaskan bahwa pada diskusi atau 
pembahasan menekankan pada sebab, bagian ini mencerminkan kemampuan berpikir kritis tentang hasil yang diperoleh. Dengan demikian, kemampuan berpikir kritis mahasiswa masih perlu dilatih dengan cara mengajarkan konsep secara kontekstual pada perkuliahan Fisiologi Hewan.

Pada kinerja ke-1, hasil temuan tentang rerata waktu koagulasi darah ternyata tidak sesuai dengan teori. Menurut teori waktu koagulasi darah yang normal berkisar antara 2-5 menit. Tapi, hasil temuan beberapa kelompok mahasiswa adalah benang-benang fibrin sebagai indikator penggumapalan darah terbentuk melebihi 5 menit. Di bagian pembahasan, mahasiswa tidak menelusuri penyebab temuan tersebut karena kemampuan berpikir kritis mahasiswa dalam menganalisa faktorfaktor yang mempengaruhi kecepatan pembentukan benang fibrin belum terlatih. Selain itu, referensi yang digunakan sebagai acuan masih kurang mencukupi untuk menganalisa hasil temuan tersebut. Menurut pendapat Tim Dosen Botani Phanerogamae (2002) bahwa aspek pembahasan mencerminkan kemampuan mahasiswa dalam berpikir kritis tentang hasil yang diperoleh. Hasil pengamatan yang diperoleh harus diolah dan dianalisis dengan menggunkan sumber pustaka yang relevan.

Bahkan pada aspek penilaian "kesesuaian rumusan simpulan dengan tujuan dan hasil" mengalami penurunan pada akhir laporan, padahal sudah meningkat di kinerja yang ke-2. Hal tersebut disebabkan mahasiswa kurang memperhatikan feedback yang disarankan oleh tim penilai. Feedback tersebut berisi tentang saran untuk memperhatikan tujuan praktikum dan hasil temuan dalam merumuskan simpulan. Berdasarkan catatan lapangan, sebagian besar mahasiswa menjelaskan sebab atau alasan dari temuan di bagian simpulan sehingga penjelasannya sangat panjang. Padahal penjelasan tersebut seharusnya ada di bagian pembahasan. Pemahaman terhadap konten Biologi juga turut andil dalam perumusan simpulan yang tepat. Pada kinerja ke-3, kemampuan mahasiswa sangat menurun karena konsep tentang osmoregulasi dinilai sangat sulit. Hal tersebut terlihat dari penjelasan mahasiswa di bagian pembahasan yang kurang tepat tentang konsep osmoregulasi, tekanan osmosis, dan proses osmosis. Pada kejadian ini, mahasiswa kurang bisa menghubungkan antara konsep yang terkait dengan praktikum, tujuan praktikum dengan hasil temuan. Seperti pendapat Rohyami (2011) yang menjelaskan bahwa simpulan berisi jawaban sesuai dengan tujuan percobaan yang ditulis dalam kalimat yang sederhana.

Dengan demikian, kemampuan komunikasi mahasiswa pada mata kuliah Fisiologi Hewan yang bermuatan praktikum berada dalam kategori cukup. Namun kemampuan komunikasi mahasiswa dalam aspek menganalisis data temuan dan membuat simpulan masih berada dalam kategori kurang/rendah.

\section{SIMPULAN DAN SARAN}

Simpulan yang dapat dirumuskan dalam penelitian ini adalah kemampuan komunikasi calon guru Biologi dalam penyusunan laporan praktikum pada mata kuliah Fisiologi Hewan dikategorikan cukup. Pemberian feedback dalam peningkatan kemampuan komunikasi calon guru Biologi dalam penyusunan laporan praktikum pada mata kuliah Fisiologi Hewan dinilai efektif, terutama pada aspek "terdapat ketepatan sistematika penulisan laporan praktikum", "kemampuan mengolah data temuan secara tepat" dan "relevansi penggunaan teori dalam menganalisis data temuan". Kemampuan mahasiswa dalam merumuskan simpulan masih harus dilatih.

Beberapa saran yang terkait dengan penelitian ini adalah perlu adanya pembekalan terkait dengan kemampuan mahasiswa calon guru Biologi dalam menganalisa faktor penyebab terhadap hasil temuan dengan teori pendukung secara kritis. 
Selian itu, perlu adanya konsistensi dari tim pengampu mata kuliah bermuatan praktikum untuk memberikan feedback terhadap kinerja mahasiswa di dalam laporan praktikum. Hal tersebut dimaksudkan agar mahasiswa mengetahui kualitas kinerjanya dan dapat memperbaikinya pada tugas selanjutnya.

\section{DAFTAR PUSTAKA}

Anugrah, D. (2011). Analisis Kemampuan Keterampilan Proses Sains dan Penguasaan Konsep dalam Mata Kuliah Fisiologi Hewan Mahasiswa Pendidikan Biologi Uhamka Semester VI serta Faktor-Faktor yang Berhubungannya. Tesis. Universitas Muhammadiyah Bengkulu. Tidak Diterbitkan.

Bundu, P. (2006). Penilaian Keterampilan Proses dan Sikap IImiah Dalam Pembelajaran Sains-SD. Departemen Pendidikan Nasional Direktorat Jenderal Pendidikan Tinggi direktorat Ketenagaan: Jakarta.

Dahar, R. W. (1996). Teori-Teori Belajar. Jakarta: Erlangga.

Jalmo, T. (2010). Pengembangan Program Pelatihan Peningkatan Kompetensi Guru IPA SMP dalam Mengonstruksi Tes. Disertasi. Universitas Pendidikan Indonesia. Bandung. Tidak Diterbitkan.

Rohyami, Y. (2011). Panduan Penulisan Laporan Praktikum. [Online] Tersedia:www.diploma.chemistry. uii.ac.id [8 Maret 2017].

Rumanta, M. dan Asiah S. (2007). Materi Pokok Fisiologi Hewan, cetakan 1. Jakarta: Universitas Terbuka.

Rustaman, N. (2002). Perencanaan dan Penilaian Praktikum di PerguruanTinggi. Program Applied Approach bagi Dosen UPI. [Online] Tersedia:http://file.upi.edu/Direkto ri/Sps/Prodi.Pendidikan_Ipa/1950 12311979032nuryani_Rustaman/ Perencanaan_Dan_Penilaian_Pr aktikum.pdf. [10 Februari 2013]
Rustaman, N.Y, Soendjojo Dirdjosoemarto, Suroso Adi Yudianto, Yusnani Achmad, Ruchji Subekti, Diana Rochintaniawati, dan Mimin Nurjhani K. (2003). Strategi Belajar Mengajar Biologi (Common Textbook, edisi revisi). Bandung: JICA UPI.

Semiawan, C., Tangyong, Belen, Yulaelawati M., Wahjudi S. (1988). Pendekatan Keterampilan Proses: Bagaimana Mengaktifkan Siswa dalam Belajar, cetakan keempat. Jakarta: PT. Gramedia.

Sukmadinata, N. S. (2011). Metode Penelitian Pendidikan: Penelitian memberikan deskripsi, eksplaanasi, prediksi, inovasi, dan juga dasar-dasar teoritis bagi pengembangan pendidikan, cetakan ketujuh. Bandung: UPI dan PT. Remaja Rosdakarya.

Tim Dosen Botani Phanerogamae. (2002). Petunjuk Praktikum Botani Phanerogamae. Bandung: JICA.

Undang-Undang Republik Indonesia No. 20 Tahun 2003. Tentang Sistem Pendidikan Nasional. Jakarta: Depdiknas.

Winatasasmita, D., Soesy A. S., Saefudin, dan Hernawati. (2008). Penuntun Praktikum Fisiologi Hewan. Bandung: UPI.

Wolf, K. and Stevens, E. (2007). The Role of Rubrics in Advancing Assessing Student Learning. The Journal of Effective Teaching, 7 (1), hlm. 3-14. [Online]. Tersedia: http://www.uncw.edu/cte/et/article s/vol7_1/wolf.pdf [21 Mei 2014] 